\title{
I utkanten av den sociala barnavården. Vem har rätt till en plats på kollo?
}

ANN-CHARLOTTE MÜNGER

Vad är det som bestämmer vilka barn och ungdomar som ska få en plats på kollo? I följande artikel ska uttagningsprocessen $i$ en kommunal koloniverksamhet stå i fokus. Studiens övergripande syfte handlar om utifrån vilka bedömningsgrunder barnen väljs ut och på vilket sätt begrepp som behov och sociala problem fär för betydelse för vilka barn som tilldelas respektive nekas en plats på kommunens sommarkollo. ${ }^{1}$

När frågor som behandlar barn och ungas behov av stöd och hjälp sätts detta oftast i relation till socialt arbete som organiseras av socialtjänstens sociala barnavård och som med stöd av socialtjänstlagen på olika sätt griper in i barn och ungdomars liv. Vad som ska inkluderas i begreppet social barnavård är däremot inte klart eftersom mycket arbete utförs av samhällsinstitutioner som står utanför socialtjänstlagens

Ann-Charlotte Münger, fil.dr, Institutionen för beteendevetenskap och lärande, Linköpings universitet. lagrum. Lundström (1996 s.12) talar därför hellre om social barnavård i en mer "utvidgad mening». Dessa »samarbetspartner» kan exempelvis finnas inom skola, skolhälsovård, barnomsorg och fritidsverksamheter av olika slag (SOU 2000:38 s.15). Dessvärre saknas oftast den här typen av verksamhe-

1 Följande undersökning om uttagningsprocessen är en del av ett större etnografiskt fältarbete om en kommunal koloniverksamhet som ägde rum mellan åren 2003-2006. Studien om koloniverksamheten är ett delprojekt inom forskningsprogrammet "Socialpedagogiken i samhället" (finansierat av Vetenskapsrådet 2003). 
ter när utsatta barns behov av stöd studeras och det är lätt att få intrycket av att barn och unga med behov och problem endast återfinns inom socialtjänstens institutionella ramverk. Men enligt många kommuner har ungas problembilder blivit alltmer komplicerade, vilket innebär att olika samhällsinstanser kan vara inblandade i enskilda barns ärende (Socialstyrelsen 2006). Institutioner och verksamheter av det här slaget kan fungera på två sätt dels som en del av den utvidgade barnavården, dvs. socialtjänsten använder sig av dess tjänster, dels som förebyggande insats då problembilden ännu inte är så pass allvarlig hos den unga att socialtjänstens regelverk måste tillämpas. Dessa så kallade "öppna insatserna» är ett frivilligt åtagande för kommunen och erbjuds och används av familjer som själva söker stöd och hjälp. Verksamheternas funktion som biståndsprövad insats och/eller service varierar däremot mellan kommuner, vilket gör att det enligt Socialstyrelsen finns anledning att se över och tydliggöra användningsområde och lagstiftning (Socialstyrelsen 2007 s. 111). En verksamhet där det råder stor variation mellan landets kommuner är satsningen på sommarkolonier. Någon offentlig statistik finns inte men enligt en Sifo-undersökning från 2005 är det två tredjedelar av landets kommuner som anordnar sommarkolonier. I undersökningen uppskattas att ett stort antal unga har behov av en strukturerad tillvaro under den tid då andra institutioner har sommarstängt (Majblomman 2005). Syftet med kolonierna formulerar en kommun på följande sätt:

\section{I första hand vill vi värna om de barn och ungdomar $i X$ kommun som behöver extra}

stöd /---/. Verksamheten syftar till att ge barnen upplevelser och erfarenheter som de annars inte skulle ha möjlighet att fä då merparten kommer frän familjer som saknar ekonomiska eller andra förutsättningar att erbjuda barnen miljöombyte under sommaren (Verksamhetsberättelse 2004). ${ }^{2}$

Erbjudandet av "extra stöd« under sommaren är ingen ny företeelse utan har rötter $i$ 1800-talets filantropiska sociala arbete. I slutet av århundradet ansågs svensk arbetarklass befinna sig i kvantitativ och kvalitativ kris. Samhällsförändringar hade medfört att fattigdomen synliggjordes på ett nytt sätt och de smutsiga och hungriga arbetarklassbarnen definierades av borgerligheten som ett socialt och politiskt problem. Sommarkolonier blev en del av det förebyggande arbetet då fattiga folkskolebarn under sommarlovet skulle byta ut det osunda hemmet mot en hälsosam landsbygdsmiljö. Koloniernas goda miljö ansågs främja barnens fysiska, psykiska och sociala hälsa och hade enligt Lindström (1989) ett klart socialpedagogiskt syfte. Verksamheten startade som ett välgörenhetsprojekt $\mathrm{i}$ slutet av 1880-talet men blev under 1930talet en statlig angelägenhet och definierades som en »institution för halvöppen barnavårdu. År 1960 övertogs ansvaret av kommunerna (SFS 1960:595).

Sommarkolonin är intressant utifrån flera aspekter eftersom den både kan användas som "samarbetspartner" till den sociala barnavården, dvs. barn anmäls till sommar-

2 Studien följer Vetenskapsrådets konfidentialitetskrav se metodavsnitt. 
vistelse av socialtjänsten, men också kan fungera som komplement till barnomsorgens fritidsverksamhet. I praktiken innebär det att verksamheten definieras som generell välfärdstjänst, då alla barn och ungdomar i en specifik åldersgrupp har rätt att söka plats på kommunens kolonier, samtidigt som uttagningsförfarandet bygger på behovsprövning utifrån en fastställd prioritetsordning. ${ }^{3}$

1. Barn som är prioriterade av sociala förvaltningen, elevvården eller andra.

2. Barn som lever med en förälder.

3. Barn som $\mathrm{p} g$ a hemförhållande behöver denna verksamhet

4. Syskon till prioriterade barn

5. Övriga (Verksamhetsberättelse 2004).

I följande artikel ska den uttagningsprocess som leder fram till ett positivt eller negativt besked om en plats på ett kommunalt kollo stå fokus. Det övergripande syftet handlar om utifrån vilka bedömningsgrunder barnen väljs ut och på vilket sätt begrepp som behov och sociala problem får betydelse för vilka barn som slutligen tilldelas respektive nekas en plats på kommunens sommarkollo.

\section{Sommarkolonin som fritidsaktivitet och socialt arbete-forskningsläge}

Utifrån ett nordiskt välfärdsperspektiv är

3 Som tidigare diskuterats råder stor variation mellan kommuner, vilket innebär att prioritetsordningen kan skilja sig åt mellan kommuner. det vetenskapliga intresset för sommarkoloniverksamhet begränsad. En förklaring kan vara att det är en svårdefinierad verksamhet då den både tangerar problemområden som finns representerad i socialt arbete och forskning som knyter an till fritidsektor och barnomsorg. Samtidigt finns gemensamma beröringspunkter då studier om fritiden kan belysa vilka barn och ungdomar som samhället bedömer vara i behov av kompensatoriska åtgärder i form av organiserad och institutionaliserad verksamhet under fritiden. Olson (1992) visar t.ex. i sin studie hur fritidspolitiska strävanden i början av 1900-talet riktades mot särskilt utsatta grupper där verksamheter som kolonier blev ett sätt för staten att kontrollera arbetarklassens barn under den farliga fritiden under sommarlovet. En av de få nationella studier där själva koloniverksamheten står i fokus är Lindströms artikel från 1996. Författaren driver här tesen att i motsats till verksamhetens syfte och målsättning om att hjälpa och vårda de mest utsatta barnen användes och utnyttjades kolonierna främst av den skötsamma delen av arbetarklassen. Risken ansågs nämligen för stor att de sociala problem som förknippades med de allra fattigaste skulle smitta ner övriga kolonister. I två tidigare studier (Münger 2000, Markström \& Münger 2004) visar även jag på uttagningens komplexitet i början av 1900-talet. Förutom kriterier som hemförhållande och hälsotillstånd fanns en mer pragmatisk orsak till att vissa barn valdes ut. För att verksamheten rent ekonomiskt skulle fungera var det t.ex. nödvändigt att det fanns äldre barn i kolonigruppen som kunde hjälpa till med hushålls- och trädgårdsarbetet. 
Om få nationella studier har publicerats om koloniverksamhet är det internationella forskningsläget ett annat där särskilt USA kan visa upp en lång forskningstradition. Henderson et al. (2007) menar att forskningsintresset sedan början av 1900-talet kan delas upp i två inriktningar: Om den första främst kan sägas intressera sig för organisation och olika aktörers upplevelser, så är frågor som berör metoder och behandlingsresultat viktiga för den andra inriktningen. Michalskis et al. (2003) studie visar t.ex. på hur ett terapeutiskt program som använts på en koloni för barn med inlärningssvårigheter och psykosociala problem resulterade i goda behandlingsresultat. Syftet med den här typen av studier är främst att se hur särskilda åtgärder/terapier fungerar för barn med diagnoser eller en social problematik. I en tidig studie från 1970-talet studeras hur barn som uppvisar ett antisocialt uppförande får ett annat beteende i väl fungerande kolonigrupper. Själva kolonigruppen användes som pedagogiskt verktyg och kunde visa på goda resultat. Hur själva uttagningen gick till och vad som definierades som antisocialt beteende diskuteras inte, men studierna är intressanta på så sätt att det visar på en pedagogik som utgår från själva gruppen och det vardagsliv som finns ute på kolonin (Wodarski et al. 1976). Även Kissmans (1999) studie beskriver hur arbetet med hemlösa använde sig av kolonier som praktisk lösning för att ordna boende men där innehållet i form av dagliga rutiner och sysselsättning samtidigt hade ett pedagogiskt syfte. De internationella studierna är intressanta på flera olika sätt och visar sommarkolonin som en viktig arena för socialt arbete både när det gäller olika klient/målgrupper och resultat av olika behandlingar/ metoder. Särskilt intressant är de studier som lyfter fram själva kolonin som en del av en större behandlingsplan. Däremot saknas studier av mer problematiserande karaktär där t.ex. målgrupp och definition av begrepp som sociala problem/behov står i fokus.

\section{Teoretiska utgångspunkter}

Studiens övergripande fråga handlar om vilka barn som erbjuds plats och vilka barn som inte får ta del av detta välfärdsprojekt. Vilka bedömningsgrunder som ställs upp och hur de används i den (administrativa) process som leder fram till ett positivt eller negativt besked om vistelse på koloni är därför av största intresse. En av samhällets viktigaste uppgifter är upptäcka de barn och ungdomar som är i behov av hjälp och måste kompenseras för att nå en tillfredställande levnadsnivå. Det är det institutionella ramverket som bestämmer vad som faller utanför och vad som kan anses som normalt accepterat i ett barns uppväxtmiljö (Andersson 2007). Ansvaret för att sätta gränsen mellan vad som kan berättiga ett samhällsingripande eller inte, ligger på kommunala förvaltningar som med stöd av ev. lagstiftning ska kunna ta beslut. Som tidigare diskuterats är det skillnad på den sociala barnavården som med stöd av lagstiftning fattar beslut om behovsprövning och hjälpinsatser och de verksamheter som erbjuder socialt stöd på frivillig basis.

Inom socialt arbete finns en lång tradition av användandet av behovsbegreppet 
för att rättfärdiga hjälp och åtgärder. Att begreppet är relativt och att definitionen och användandet måste sättas in i sitt samhälleliga, historiska, sociala och kulturella sammanhang är något som länge diskuterats både inom forskningen och ute i verksamheterna (Smith 1980, Andersson \& Hollander 1996). Under senare år, menar Axford (2008), har behovsbegreppet fått en allt större betydelse vid fördelningen av samhällsinstitutionernas resurser. Inom den sociala barnavården har därför metoder utvecklats för att kunna mäta och bedöma barns behov på ett tillförlitligt sätt. Gemensamt för flera av de bedömningssystem som idag används inom det internationella barnavårdsfältet är att de, till skillnad från tidigare, grundar sig på en helhetssyn på barnens utveckling och totala livssituation. Detta åskådliggörs i den s.k. behovstriangel som fått stor betydelse i utformandet av ett strukturerat bedömningsverktyg där samspelet mellan barns utvecklingsbehov, föräldrars förmåga samt familj- och miljömässiga blir en central utgångspunkt $i$ bedömningen av ett barns behov av insats (Ward 2002, Cleaver 2004). Inom svensk barnavård återfinns detta i handläggningsoch dokumentationssystemet Barns behov $i$ centrum (BBIC) som ska ge struktur för ett systematiskt arbete $\mathrm{i}$ barnavårdsärenden. Fördelar med den här typen av generella bedömningssystem är flera, dels ger det struktur för ett mer systematiskt sätt att dokumentera och följa upp barn och ungas behov av insatser, dels förväntas de bidra till nationell enhetlighet $i$ hanterandet av barnavårdsärenden. Arbetet med en väl utvecklad metodik av behovsprövning har varit så lyckat, anser Socialstyrelsen, att det också bör prövas i kommunala verksamheter som står utanför den sociala barnavården. Planer finns därför att utveckla ett enklare kartläggningssystem som ska finnas tillgängliga i de "öppna insatser» dit familjer själva söker hjälp och stöd. Behovstriangeln skulle på så sätt kunna fungera förebyggande eftersom hjälpen till barn som är i "behov av stöd" sätts in på ett "tidigt stadium» $i$ »just de verksamheter där barnen befinner sig" (Socialstyrelsen 2007 s.111). Axford (2008) ser stora fördelar med bedömningsinstrument av det här slaget, men menar samtidigt att det är viktigt att diskutera och problematisera vad för slags behov som egentligen diskuteras men också var gränsen ska sättas för att ett ingripande ska kunna motiveras. Problemet är, fortsätter Axford, att behov kan definieras på olika sätt: (i) utifrån myndigheternas beräknande av vilka behov som finns (ii) genom att mäta de sammanlagda behoven hos servicemottagarna utifrån områdets specifika sociala och demografiska karaktär, (iii) i individuella klienters egna uttryckta behov och (iv) att behovet fastställs utifrån en expertdefinierad norm. I de instrument som utvecklats för att bedöma barns behov kombineras oftast flera av definitionerna, vilket kan innebära att det kan vara svårt att veta vad för slags behov som egentligen bedöms och åtgärdas. Svårigheten att definiera och behovsbegreppets otydlighet gör det problematiskt att använda menar Sheppard och Woodcook (1999) som istället efterlyser ett mer operativt handlingsbegrepp där det är problemet som ska åtgärdas som står i fokus. Författarna formulerar det på följande sätt: "We are no longer looking at specifik need areas, from which a taxonomy 
of need is created. We are definining needs in terms of problem areas" (a.a. 74). Behovsbegreppet blir i deras resonemang nära förknippat med diskursen om sociala problem. Teoretiskt innebär detta att sociala behov/ problem inte kan ses som givna och naturliga fenomen utan något som konstrueras i den praktik där de behandlas (Parton et al. 1997). Ett exempel på detta är den viktiga distinktion som görs mellan att vara ett socialt problem eller att ha ett socialt problem. Distinktionen blir särskilt tydlig när förhållande mellan föräldrar/familj och det enskilda barnet diskuteras: Är det barnets beteende som ska korrigeras eller ska problemet ses som en ett uttryck för en familjeproblematik? Problemet anses oftast finnas hos föräldrarna eller brister i hemmiljön när kompensatoriska åtgärder planeras menar Egelund (2004). I utredningssammanhang blir det särskilt tydligt då barn till utlandsfödda diskuteras (Andersen 2004) eller som Petersson (2006) visar på de olika krav som ställs på mödrar och fäders föräldraskap (jfr. Lundström \& Sallnäs 2003). Påtalade brister i ansvarstagande hos t.ex. fäder eller föräldrar med annan etnisk bakgrund har ofta en moralisk dimension som både kan finnas inbyggd i det institutionella ramverket och hos den enskilda socialarbetaren. Det kan innebära att personliga erfarenheter och kunskaper av en klient blir avgörande för hur bedömningen av ett fall kommer att utvecklas (White 2003, Egelund 2004, Rieman 2005). Det kan vara en del av förklaringen till den stora variation som finns både inom samma kommun som mellan kommuner i hanteringen av barnavårdsärenden (Wiklund 2006, Cocozza 2007).

\section{Metod och material}

Vid det fältarbete som genomfördes under sommaren 2003 inom en kommunal koloniverksamhet blev det tydligt för mig att personalen hade frågor kring uttagningen och vilka behov som ansågs motivera en plats på kolonin (se not 1). Jag beslöt därför att året efter, genom (deltagande) observation som metod, följa den uttagningsprocess som äger rum varje år då arbetet med att välja ut de barn och ungdomar som ska få en koloniplats äger rum. Under två vårkvällar (sammanlagt tio timmar) samlades den grupp som hade till uppgift att välja ut de barn och ungdomar som skulle tilldelas en plats på kommunens internatkoloni. Mötena, som var mycket informella med livliga diskussioner och skratt, ägde rum på en social enhet inom kommunen där vi satt runt ett soffbord i ett besöksrum från ca 17 till 22-tiden. Gruppen bestod av, förutom mig som observatör, den kvinnliga enhetschefen (här förkortad EC) samt två kvinnliga barnledare (BL 1 och 2). Samtlig mötestid har spelats in med bandspelare. Det tio timmar inspelade observationsmaterialet har transkriberats och analyserats och omfattar 104 sidor. $^{4}$ De två mötena kan liknas vid ett långt pågående samtal där jag intog rollen som perifer deltagare, dvs. jag ställde frågor och bad om förklaringar då något framstod som oklart men deltog inte i själva diskussionerna. Till sin hjälp i arbetet med uttagningen använde sig gruppen av dokument av olika slag, vilket bestod av ansökningshand-

4 Samtliga citat är, om inte annat anges, hämtad ifrån det transkriberade observationsmaterialet, i fortsättningen förkortat DO.

Ann-Charlotte Münger: I utkanten av den sociala barnavården. 
lingar (179 st.) och de s.k. barnstaplarna (84 st., angående barnstaplarna se vidare s. 193). I det här sammanhanget är det inte dokumenten i sig som står i fokus utan hur personalen använde sig och relaterade till dem $i$ arbetet med att bedöma de sökandes behov. Vid tre tillfällen då själva arbetet med uttagningen låg nere utvecklades samtalen mellan mig och deltagarna till att bli ostrukturerade intervjuer. En av dessa intervjuer finns inspelad eftersom bandspelaren fortfarande stod på (DO s. 35-36, intervju 1). Vid de andra tillfällena fördes samtalet vid kaffeautomaten en bit bort, vilket innebar att det endast finns anteckningar från intervjuerna (Intervju 2 och 3).

Observationen gav en unik förståelse genom de direkta erfarenheter jag som forskare fick ta del av hur gruppen diskuterade, förhandlade och beslutade om det enskilda barnets behov av en koloniplats eller inte. Den personliga närvaron vid mötena gav mig en helhetsbild av uttagningens komplexa process där möjligheten att ställa frågor ökade förståelsen av vissa företeelser som kom fram under det pågående samtalet (Atkinson et al. 2001).

\section{Förförståelse och analysprocess}

Valet att just följa uttagningen utgick från mina erfarenheter från föregående sommars fältarbete då personalen ibland ifrågasatte uttagningsgruppens val av barn. I diskussionerna användes då ofta begrepp som behov och problem. Jag gick alltså in i fältarbetet med en förförståelse om betydelsen av vissa begrepp, vilket både kom att påverka val av syfte och analysingångar till det empiriska materialet. Arbetsgången kan beskrivas som abduktiv då analysprocessen utgick från växelverkan mellan teori och empiri där kunskaper om teorier kring begreppen skapade förståelse av det empiriska materialet, samtidigt som tolkningen av empirin gav nya teoretiska insikter (Mason 2002 s. 180). Tolkningsarbetet kan ses som en ständigt pågående process med tre analytiska nivåer där tolkningen av första graden innebar ett konstaterande av vad som uttryckts, vilket i själva verkat handlade om att skapa ett underlag för det fortsatta tolkningsarbetet. I den här fasen blev det betydelsefullt att fastställa vilka begrepp som förekom och hur de användes. Här blev det tydligt att förutom behov var begrepp som problem och grupp något som ofta förekom i diskussionerna. Förutom att besluta vilka begrepp som var centrala var det viktigt att i den här delen av analysen förstå dokumentens funktion och hur de användes i uttagningsprocessen.

I tolkningen av andra graden lyftes begreppens mer vardagsnära användning in i den teoretiska referensramen. Begreppen började på så sätt att abstraheras och kunde ses som ett utryck för de sociala och kulturella processer som styrde uttagningen, vilket ytterligare utvecklades i tolkningens tredje fas. Här låg fokus på att uppmärksamma om det fanns dolda intressen och drivkrafter bakom uttagningen och hur ett sådant mönster skulle kunna tolkas och förstås (Fangen 2005 s. 224-254).

Den använda tolkningsmodellen kan innebära forskningsetiska dilemman då teoretiseringen av det studerade fenomenet inte överensstämmer med informanternas bild av händelseförloppet. I den här studien 
har det därför varit särskilt viktigt att noggrant följa Vetenskapsrådets informationsoch samtyckeskravet (Vetenskapsrådet 2002). Det har också varit viktigt att följa konfidentialitetskravet som i den här studien innebär att såväl kommun, verksamhet, personal som sökande har avidentifierats. Samtliga namn är fingerade. Samtidigt är det viktigt att påpeka att det är processen av uttagningen som står i fokus och inte uttagningen av det enskilda barnet. Citaten som används måste därför förstås utifrån sitt sammanhang och inte sättas i samband med prövningen av ett enskilt barn och dennes behov eller problem.

\section{Uttagningsprocessen}

\section{Den adminstrativa gången}

I en medelstor svensk kommun bedrivs koloniverksamhet med omkring 600 platser fördelade på internat och dagkolonier. Verksamheten har en lång tradition då den första kolonin som var i privat regi sändes ut i slutet av 1800-talet men övergick i mitten av 1960-talet till att bli en kommunal angelägenhet. Idag fungerar den som en självständig enhet inom kommunens öppenvårdsverksamhet. På enheten finns en enhetschef anställd på heltid medan övrig personal är tim- och säsongsanställd (Verksamhetsberättelser 1960-2008).

Gruppen som för året ansvarar för uttagningen består av enhetschefen samt två säsongsanställda, s.k. barnledare. De får ersättning per timme men arbetar annars heltid inom barnomsorgen. Det finns inga formella riktlinjer om hur sammansätt- ningen av den grupp som har ansvaret för uttagningen ska se ut eller hur den ska arbeta. Men det bästa är, enligt en av barnledarna, att enhetschefen finns med liksom flera barnledare. Vilka som arbetar med den här uppgiften beror helt och hållet på vem som har tid och möjlighet, vilket gör att uttagningsgruppen kan se olika ut år från år. Året innan sköttes uttagningen helt av en ensam barnledare. Uttagningsgången beskrivs på följande sätt: Alla barn i åldrarna 9-16 har rätt att söka och i slutet av mars annonserar verksamheten i länets dagstidningar och information/blanketter finns på kommunens hemsida. Information skickas också ut till socialtjänsten $\mathrm{mm}$. Det viktigaste informationskanalen är skolan och enheten skickar ut ansökningsblanketter till kommunens samtliga skolor. Skolorna har ingen skyldighet att dela ut blanketterna utan det är upp till varje skola om de vill bistå med hjälp. På vissa skolor delas de ut medan andra skolledare/lärare menar att det inte är deras uppgift och ansvar. Skolornas ovilja att lämna ut blanketter liksom barnens slarv gör att många föräldrar aldrig får ta del av informationen (Intervju 2 och 3).

Enhetschefen har förberett arbetet genom att lägga ansökningshandlingar i ordning, dvs. sorterade efter perioder och kön. Fyra högar ligger på ett bord. I en femte finns de s.k. barnstaplarna. Arbetet går till på det sättet att varje ansökan diskuteras genom att uppgifter från ansökan och ev. barnstapel förs samman med barnledarnas personliga erfarenheter och uppfattningar om den sökande. Detta innebär att det är mycket diskussion kring uppgifter som visar på behov/problem och barnets möjlighet att passa in på kollo. 
Uttagningsarbetet kan sägas utgå från fasta kategorier som ålder och kön där varje period ska vara jämnt fördelad mellan könen och barnen ska finnas inom ett givet ålderspann. Uttagningen ska således resultera i att 120 barn, 60 pojkar och 60 flickor blir fördelade och placerade på fyra olika perioder. Uppdelningen är inget som diskuteras i gruppen utan fördelningen i pojkrespektive flickhögar till respektive period genomförs utan diskussion. Något som inte heller diskuteras öppet på de båda mötena är det informella mål som finns om gruppens sammansättning. En av barnledarna berättar för mig att det finns en oskriven regel vid uttagningsförfarandet att en tredjedel av platserna ska gå till barn med social förtur, en tredjedel till barn som varit med förut och en tredjedel till barn som inte har sociala behov/problem. Att den sista tredjedelen består av barn utan någon särskild problematik är oerhört viktigt. Det behövs trygga, stabila eller "helt vanliga barn", som barnledaren uttrycker det, för att skapa en fungerade grupp och blandningen av barn har därför stor betydelse. Till sin hjälp med att dela in barnen i de olika grupperna finns olika hjälpmedel att ta till. Förutom dokument som ansökningshandlingar och barnstaplar är den personliga kännedomen och erfarenheten det viktigaste redskapet, menar en av barnledarna (Intervju 2).

\section{Bedömningsverktyg \\ - dokument och egna erfarenheter}

Varje ansökan utgår från den ansökningsblankett som skickats in av vårdnadstagare.
För barn som inte tidigare varit på koloni är blanketten det enda som uttagningsgruppen har att utgå ifrån. På blankettens framsida ska uppgifter om föräldrarnas arbete och civilstånd fyllas i »då är det framsidan vi har att gå på och här står det bara mamma, då kan det vara en prioritet före någon annan«. Uppgifter om föräldrars sjukskrivning, arbetslöshet och/eller att de är ensamstående visar att de är behov av en plats. Det är ett trubbigt instrument men är ibland den enda information man kan få, menar en av barnledaren. Vilka barn som väljs ut efter den prioriteten är oklart men kan med utomstående ögon te sig relativt slumpartat. När en av barnledarna letar i högen med ansökningar där endast framsidan är ifylld så väljs den första ut: »här står det en utan pappa så den tar vi«. Här var det uppgiften om skilda föräldrar som blev avgörande men även uppgift om föräldrarnas arbete, eller avsaknad av arbetet, kan få betydelse: "och mamman har inget yrke, det står streck på båda, hon skulle kunna vara lite, lite prioriterad utav oss". Barn som lever i en kärnfamilj där föräldrarna har arbete blir däremot tidigt utgallrade: »här är hugget som stucket, det står inget på... alla har jobb, alla har mamma och pappa« (BL 1). Uppgifter av det här slaget kan inte motivera en plats menar barnledarna.

På andra ansökningar kan även "Övriga upplysningar" på blankettens baksida vara ifylld men informationen är svårbedömd menar en av barnledarna: Många föräldrar använder den enligt sina egna behov och skriver därför inte ut den kunskap som behövs för en relevant bedömning. Risken är då stor att det blir problem. Barnledaren fortsätter: 
BL2: Och en del tror ju att skriver jag någonting så kanske jag inte kommer ut, törs inte för att vi ska tycka det verkar jobbigt...så det kan vara så att det inte står någonting och så kommer de ut och wow...hur mycket som helst, kalabalik! /---/för det var ju en period, det var allmänt kaos, för vi hade tagit två, tre barn med diagnos /---/ och så kom det ut flera stycken till.

I andra fall kan enbart de uppgifter som finns under rubriken "Övriga upplysningar" räcka för att gruppen ska bedöma att den sökande är i behov av plats. Detta blir tydligt när Albins ansökan ska behandlas. Föräldrarna är gifta och har arbete men det framgår i ansökan att pojken är mycket ensam. Beskrivningen av pojkens utsatthet är välformulerad och lämnar ingen oberörd och hela uttagningsgruppen reagerar på pojkens svåra situation och en av barnledarna menar "då är han ju prioriterad hos oss, tycker jag". Hur stor roll den välskrivna ansökan spelar in i beslutet är svårt att avgöra men pojken tilldelas en plats utan diskussion.

Om anmälningsblanketten är uttagningsgruppens enda bedömningsinstrument för förstagångssökande är förutsättningarna andra för de barn som tidigare varit på koloni. Det kan ibland vara till fördel för barnet, vilket är fallet med pojken Robert. En av barnledarna har positiva minnen: "JAA...Han både behöver kollo, kollo behöver honom, gud vilken unge. En rolig en, jätteroligw. Andra erfarenheter kan däremot vara till nackdel. En pojke bedöms av samma barnledare vara en "smygjävel" vilket resulterar i att "den plockar vi bort«. Pojken finns inom den sociala barnavården men detta diskuteras inte utan beslutet att inte välja ut honom bygger enbart på barnledarens negativa erfarenheter.

Den personliga kännedomen om barnen anser barnledarna är ett ovärderligt instrument, men trots att de båda var engagerade under största delen av föregående sommars verksamhet så räcker inte den egna erfarenheten till. De så kallade barnstaplarna blir här ett viktigt komplement. Såhär beskrivs stapelns syfte och utformning: I slutet av varje period sammanställer den fadder som har haft ansvaret för barnet en barnstapel..$^{5}$ Syftet med stapeln är att den ska vara till hjälp vid nästa års uttagning men också fungera som en slags ıjournal«. Blanketten är uppdelad i sex områden under rubrikerna: mat, bad, fria respektive planerade aktiviteter och hur kontakten med andra barn respektive vuxna fungerar. När barnstapeln är klar ska varje område vara ifyllt med någon av färgerna grönt, gult eller rött. Färgerna signalerar följande enligt barnledarna:

Det finns gul och grön att välja på och det är grönt så är allt ok, gul är lite varning då ska man skriva nånting och rött då är det varning, rött har vi sagt att då är det svårhanterligt (BL 1).

Barnstaplarna används flitigt under uttagningsarbetet och utifrån färgerna förs resonemang om barnens lämplighet att vistas på koloni. Vid flera tillfällen får barnledarnas egna minnesbilder betydelse för hur färgerna på barnstapeln ska tolkas och användas. De är tveksamma till en flicka som har

5 Begreppet barnstapel kommer ifrån att det till en början var tänkt att det skulle gå att gradera barnets beteende. 
en gul markering på kompisrelationer och som de minns som "bossig /---/ och kollo behöver inte henne". I ett annat ärende kan den färgmarkering som ska signalera observandum för uttagningsgruppen, tyckas få en underordnad betydelse. Pojken kommer från en »jättegullig familj/---/han är visst lite gul där " (skratt). I det här fallet är det snarare barnledarnas minnen och erfarenheter av familjen som blir betydelsefull i bedömningen. Förutom färgmarkeringar och kommentar ska varje barnstapel innehålla uppgifter om "barnet behöver kollo» men också om »kollo behöver barnet». En av dem menar att det är viktig information:

Ja för en del barn behöver kollo, men vi behöver inte honom men en del barn kan vara bra för kollo, kan göra bra, bidrar med bra saker /---leller är så himla positiv till alla aktiviteter (BL 1).

Barn som får markeringen "behöver kollo» bedöms av uttagningsgruppen ha behov av något slag. Det kan vara på grund av diagnos som det är med pojken Arvid. En av barnledarna läser i barnstapeln: "han behöver kollo men kollo behöver verkligen inte /honom/«. I andra fall finns det inte något behov enligt barnstapelns uppgifter. Enhetschefen läser ur barnstapeln: "han behöver inte kollo" och påpekar att meningen är understruken. Ibland sammanfaller behoven, dvs. barnet anses ha behov samtidigt som barnet kan bli en tillgång till barngruppen. Noteringen på barnstapeln om barnens behov av kolonivistelse men också kolonins behov av barnet visar på den stora betydelse och utrymme som själva begreppet har vid uttagningen.

\section{"Barnet behöver kollo"}

I de officiella dokument som ska ligga till grund för uttagningen finns en officiell prioritetsordning där barns behov graderas utifrån fem punkter (s. 186). Under de två möten hänvisar inte gruppen direkt till den men det framgår ändå av diskussionen att styrdokumentet är känt . Det blir särskilt tydligt när det gäller prioritet ett, dvs. där det finns ett intyg från myndigheterna i ansökan. Även ofullständiga ansökningar som skickats in försent ges automatiskt förtur: "har det funnits intyg från soc så har jag slängt med dem då är det inget att tveka om» (EC). Under dessa två möten påtalar enhetschefen vid flera tillfällen hur viktigt det är att ta hänsyn till att vissa barn är prioriterade från myndigheterna och därför måste behandlas på ett särskilt sätt: "vi får kolla upp alla dom här $i$ min pärm /---/ så vi inte missar någon här, känner jag". Uttalandet "vi har fätt lite prioriteringar ändå" kan därför tolkas som att hon känner en viss lättnad att ett visst antal av dem som kan anses som högprioriterade återfinns i gruppen som valts ut.

Om det hos enhetschefen tydligt framgår att det finns en medvetenhet att särskilda hänsyn till barn med prioritet ett måste uppmärksammas, framgår det inte lika klart hur uttagningsgruppen förhåller sig till de andra prioriteringarna. Diskussionerna förs istället utifrån behovsbegreppet. En av barnledarna har stor kunskap om en familj där modern lämnat hemmet och en diskussion om faderns och barnets utsatthet avslutas med orden att pojken »behöver verkligen det här". I ett annat ärende blir uppgiften om att modern »bara stack för 
länge sedan /---/ bara försvann" en viktig motivering till varför pojken Hugo skulle få en plats. Däremot är det mer oklart varför uppgiften om att spappan är väldigt frusökande" också förs fram i resonemanget. När bedömningen av ett barns behov diskuteras så handlar det i själva verket ofta om att det är problem inom familjen. I ett av ärenden har en av barnledarna mött familjen i sitt arbete: "jag har den familjen och dom behöver, tycker jag, verkligen". Enhetschefen bekräftar bilden av en problemfamilj genom att berätta vad hon hört: "Ja, Roger /en annan barnledare/ pratar ofta om dem". Samma resonemang om att problemet ligger hos familjen förs också när ett syskonpar diskuteras: "barnen $i$ sig tror jag inte blir några problem«. Att det är "familjesituationen" där mamman inte kan "sätta gränser och är väldigt svag" som anses vara problemet och motiverar plats för syskonparet, framstår som tämligen klart.

Vilka kriterier som ligger till grund för att hemförhållande ska anses som problematiska och av den orsaken ge företräde till koloniplats hos uttagningsgruppen är inget som diskuteras. Samtidigt visar vissa uttalanden att det hos gruppen ändå finns en klar bild över hur hemförhållanden ska se ut för att motivera hjälp från offentliga institutioner. Föräldrar kan t.ex. definieras som speciella: "men det är säkert en tjej som behöver prioriteras utifrain att pappan /är/ mycket speciell, han har ringt och han har propsat och han har varit här och propsat på besked (EC). Synen på föräldrarna blir också tydlig när en diskussion förs om hur lång tid föräldrarna ska få för att tacka ja eller ge återbud till erbjuden plats: En av barnledarna menar "dom fär kort tid att bekräfta men det är bra annars hinner dom bara slarvabort papperen «.

Familjer med annan etnisk bakgrund än den svenska uppfattas ha särskilda problem med den administrativa gången, "det är föräldrar som kommer och vill ha hjälp att fylla i«. Förutom svårigheten med de administrativa rutinerna verkar det hos uttagningsgruppen finnas en allmän uppfattning om att "invandrarungdomar" har särskilt behov av samhälleliga hjälpinsatser. Vad det är för behov som just de här barnen anses ha diskuteras däremot inte. På samma gång anser uttagningsgruppen att gruppen barn med annan etnisk bakgrund är viktig för verksamheten: "här är jättekul för här på nya har vi många invandrarbarn/---/jag tycker vi behöver dom».

\section{Vad "kollobehöver"}

Barn med annan etnisk bakgrund anses således vara viktig för verksamheten. Såhär kommenteras en barnstapel där det framgår att pojken Saed både behöver kollo och att kollo behöver honom: "han behöver ju, han är ju kollo. Och vi vill ha lite invandrare, han är verkligen en goding". I det här fallet sammanföll de båda behoven (dvs. eftersom barnet hade en annan etnisk bakgrund ansågs han behöva kollo samtidigt som han bedömdes kunna bli en tillgång för verksamheten). Andra ärenden kan vara mera problematiska att ta ställning till. Erik definieras som en »klippa» men anses inte ha behov av kollo:

\section{BL 2: Han var ju skitbra \\ BL 1: men han behöver inte kollo}


BL 2: nää men kollo behöver honom...han är ju en bra kille som om man ska väga upp lite /EC läser ur barnstapeln att han inte behöver kollo och att detta är understryket/ BL 2: nää han behöver verkligen inte det /---/ men står det mellan någon ny som det inte står någonting om så kan man ju lika gärna tahonom.

EC: ja...mer behov men ändå en klippa.

Däremot blir kamraten Viktor ett självklart val då han enligt barnstapeln både är en tillgång till gruppen och har enligt barnledarna "mer behov«. Vari detta behov består av diskuteras inte men så här förs diskussionen om varför han bör väljas ut.

BL 1: han är grön, han behöver kollo och kollo behöver honom/läser ur barnstapeln/

BL 2: han tycker jag, han behöver.

De här barnen ses som viktiga för gruppen och för att det praktiska ska fungera menar en av barnledarna (Intervju 2).

\section{Skapandet av en fungerande grupp}

Ett av uttagningsgruppens viktigaste arbete är, enligt barnledarna, att försöka få till en bra barngrupp. Här blir barn som definieras som "säkra kort» en viktig del i den tredjedel av barn utan problematik som bör finnas på varje period. Den andra tredjedelen ska omfatta barn som varit på koloni tidigare, vilket gör att det är naturligt att dessa kategorier sammanfaller. En flicka "fungerar jättebra" och blir uttagen då den aktuella perioden anses behöva »lite gamla också och inte bara nya". I andra fall kan den tidigare vistelsen ligga den sökande i fatet. Barnledaren: "så Victor skulle vi kunna plocka bort, för han behöver, enligt mig, inte kollo". Eftersom det redan är ganska tungt på den här perioden menar den andra barnledaren att de kan vänta och se:

BL 1: eftersom det ser mastigt ut och det är mycket gamla så behöver han nog inte kollo så vi lägger honom åt sidan så länge...vi kan se hur mycket annat vi fär.

Ordvalet "annat« ska i det här fallet kopplas samman med barn som har förtur till en plats enligt prioritet ett. För barnledarna är detta ett viktigt uttagningskriterium men måste vägas samman med andra omständigheter. Innan ett beslut ska fattas vill de därför gärna »kolla upp det lite /---/och få mer kött på benen«. Det kan vara viktigt att försöka förklara för en socialsekreterare som skickat in en ansökan, vad en kolonivistelse innebär:

BL I: ibland kan det vara bra att förklara lite hur det ser ut hos oss, så kanske dom ser att det kanske inte skulle gå/---/ibland när man pratar med socialsekreteraren 'jo det verkar bra men så när man förklarar så/socialsekreteraren inser att barnet inte passar på koloni/.

Kontakten med "soc» är inte helt problemfri menar barnledarna. Det är viktigt att etablera kontakt med socialtjänsten men menar samtidigt att socialsekreterarna inte alltid ger dem den efterfrågade informationen. En barnledare beskriver på följande sätt ett samtal hon haft med en socialse- 
kreterare: "Nää, vi vågar inte, vi har tystnadsplikt /härmar soc. sekr/ men det har ju vi med, dom visste inte om dom vågade säga det«(BL 1). Det är således viktigt att undersöka om den sökande kan anses passa på koloni men lika betydelsefullt är det att se hur tungt belastad perioden kan tänkas bli: "Nu måste vi tänka så vi inte tar ut för mycket prio...alltså, vad ska man säga...att vi inte tar ut för mycket jobb, det måste ju funka en period»(BL 1).

Lite senare i diskussionen menar en av barnledarna att det nu börjar bli för stort antal barn med en dokumenterad problematik: "Hur många har vi en, två, tre, fyra, fem, sex, sju och så kollar du dom först innan vi gör något drastiskt för nu verkar det vara lite mycket «(BL 1).

Men de här barnen behöver inte utgöra något problem, menar barnledaren. Jonna har en diagnostiserad damp "men hon brukar inte vara något problem på kollo så henne tycker jag absolut". Det är intressant att se den sekundära betydelse diagnosen får i det här fallet. Eftersom hon inte anses utgöra något problem blir hon istället den ideala kolonisten. Vid sidan av behovsfrågan är det således den sökandes förutsättningar att (inte) passa in på kollo och fungera i grupp som får betydelse i den uttagningsprocess som bestämmer vilka barn som slutligen (inte) får en plats på kommunens sommarkolonier.

\section{Sammanfattande diskussion}

Sommarkoloniverksamheten är en svårdefinierad välfärdstjänst då den både kan ses som "samarbetspartner" till den sociala barnavården och som en "öppen insats" inom kommunens sociala arbete. Det behöver naturligtvis inte innebära en motsättning i sig men hur verksamhetens uppdrag ska förstås blir oklart, då den fungerar som generell åtgärd och riktar sig till samtliga barn inom ett visst ålderspann samtidigt som uttagningsförfarandet bygger på behovsprövning utifrån en prioritetsordning. Att otydligheten i verksamhetens uppdrag får konsekvenser för uttagningsgruppens arbete måste ses som självklar och kan också förklara på det sätt som behovsbegreppet används och tillämpas i uttagningsprocessen. Den prioritetsordningen som ligger till grund för uttagningen är väldigt allmän hållen, vilket innebär att det t.ex. ligger hos uttagningsgruppen att definiera vilka "hemförhållande» som ska ligga till grund för ett positivt uttagningsbesked. Barn till föräldrar som är skilda, arbetslösa och/eller sjukskrivna bedöms vara i behov av en koloniplats. Särskilt observeras de familjer där barnen lever med en ensamstående pappa och barn i familjer med annan etnisk bakgrund. Om detta har att göra med att andra kravnivåer sätts upp för de här familjerna är svårt att avgöra men klart är att sökarljuset är mer fokuserat på dessa familjer (jfr. Lundström \& Sallnäs 2003, Andersen 2004, Petersson 2006). Vilka bedömningsgrunder som ligger till grund för att uppmärksamheten riktas mot just de här familjerna framgår inte, och det är lätt att få intrycket att det är personliga erfarenheter (personalen känner till familjerna) och moraliska ställningstagande, som bestämmer vad för slags behov som uttagningsgruppen anser kräva att en kompensatorisk åtgärd behöver sättas in under bar- 
nens fritid (jfr. White 2003, Rieman 2005). Att samhället också är mer benäget att gripa in när problemet anses ligga i barnens hemmiljö än hos det enskilda barnet är enligt Egelund (2004) ett välkänt fenomen inom det sociala arbetet (jfr. Lindström 1989, Olson 1992). Om samma mönster återfinns i uttagningen av kolonister är svårt att avgöra, men att personalen tydligt uttrycker att barnet i sig inte blir något bekymmer utan att problematiken ligger inom familjen kan tolkas i den riktningen. Utifrån Sheppard och Woodcooks (1999) resonemang skulle detta kunna tolkas som att bedömningen av barnen utgår från ett mer operativt handlingsbegrepp där det i själva verket är problembilden som står i fokus. På så sätt skulle också uttagningsgruppen till synes synonyma användning av begreppen behov och problem kunna förstås. Det är, utifrån en mer konstruktivistisk ansats, snarare det institutionella sammanhanget som bestämmer begreppets användningsområde än en vedertagen expertdefinierad norm (Parton et al. 1997, jfr. även Axford 2007).

Det skulle också kunna förklara det pragmatiska förhållningssätt som styr uttagningsgruppens arbete. För att perioden ska fungera krävs en bra sammansatt kolonigrupp vilket t.ex innebär att det inte får bli för många problembarn på en period. Inte heller får barns problematik vara för svår och kan i praktiken innebära att barn som har högsta prioritet inte väljs ut. Kolonin har däremot behov av den tredjedel "vanliga barn" eller "säkra kort» som behövs för att få gruppen att fungera. Barns (o)förmåga att passa in i kolonigruppen blir på så sätt ett urvalskriterium vid bedömningen av de sökande. Uttagningsgruppens viktigaste uppgift kan därför sägas vara att jämka ihop gruppens/verksamhetens behov med det enskilda barnets behov (jfr. Wodarski et al. 1976, Kissman 1999, Markström \& Münger 2004 om gruppens betydelse).

Att behovsbegreppet har stor betydelse vid uttagningen kan tyckas självklar men hur det ska förstås och tolkas är däremot mer oklart då innebörden snarare verkar vara situationsbundet än bygga på en teoretiskt förankrad definition. Oklarheten i begreppsanvändningen får direkta återverkningar i det konkreta arbetet och det är därför lätt att få intrycket att bedömningen av barns behov snarare bygger på personalens egna subjektiva värderingar än en objektiv bedömning som utgår från en kunskapsbaserad praktik. Axford (2007) ser den problematik som finns inbyggd i själva behovsbegreppet men menar samtidigt att lösningen finns i generella bedömningssystem som t.ex. BBIC. Införandet av system av det här slaget är en bra utgångspunkt för att komma till rätta med de stora bedömningsproblem som både finns inom den sociala barnavården och $\mathrm{i}$ många öppna institutioner inom det sociala arbetet (Cocozza 2007, Socialstyrelsen 2007). Det kan därför bli aktuellt, menar Socialstyrelsen (2007) att arbeta med ett liknande men förenklat bedömningssystem som BBIC i kommunernas öppenvårdsverksamheter. På så sätt skulle kvalitén även kunna säkerhetsställas för de barn och unga som befinner sig i verksamheter utanför den sociala barnavården. 


\section{Referenser}

Andersen, Kathrine (2004) „Invandrerbarn leger dårligt; institutionel konstruktion af farlig fritid." I Margaretha Järvinen \& Nanna MikMeyer (red.) At skabe en klient. Institutionelle identiteter $i$ socialt arbejde. Köpenhhamn: Hans Reitzels Forlag.

Andersson, Gunvor \& Hollander, Anna (1996) „Om barns rätt och barns behov". I Gunvor Andersson (red.) Barnet i den sociala barnavairden. Stockholm: Liber.

Andersson, Gunvor (2007) „Normalitetens gränser i social barnavård". I Kerstin Svensson (red.) Normer och normalitet $i$ socialt arbete. Lund: Studentlitteratur.

Atkinson Paul, Coffey Amanda, Delamont Sara \& Lofland Lyn (2001) (red.) Handbook of Etnhnography. London: SAGE Publications.

Axford, Nick (2008) "Conducting Needs Assessments in Children's Services". British Journal of Social Work august, pp. 1-22.

Cleaver, Hedy (2004) (red.) Assessing Children's Need and Circumstances: The impact of Assessment Framework. Philadelphia: Jessica Kingsleys Publishers.

Cocozza, Madeleine (2007) The Parenting of Society. A Study of Child Protection in Sweden - from Report to Support. Linköping: Linköpings universitet.

Egelund, Tine (2004) " 'Farliga foraeldre': den institutionella konstruktionen af dem, der afviger fra os". I Margaretha Järvinen \& Nanna MikMeyer (red.) At skabe en klient. Institutionelle identiteter $i$ socialt arbejde. Köpenhamn: Hans Reitzels Forlag.

Fangen, Katrine (2005) Deltagande observation. Malmö: Liber.

Henderson Karla, Bialeschki Deborah \& James Penny (2007) "Overview of Camp Research", Child and Adolescent Psychiatric Clinics of North America vol. 16, nr 4, pp.755-767.

Kissman, Kris (1999) "Respite from Stress and Other Service Needs of Homeless Families", Community Mental Health Journal vol. 35, nr 3, pp. 241- 249.
Lindström, Lars (1989) "Om skollofskolonier". Nordisk pedagogik vol. 9, nr 1, s. 24-34.

Lundström, Tommy (1996) „Den sociala barnavården«. I Gunvor Andersson, Karin Aronsson, Sven Hessle, Anna Hollander \& Tommy Lundström (red.) Barnet i den sociala barnavården. Stockholm: Liber AB.

Lundström, Tommy \& Sallnäs, Marie (2003) »Klass, kön och etnicitet i den sociala barnvården", Socialvetenskaplig tidskrift vol. 10, $\mathrm{nr} 2-3$, s. 193-213.

Majblommans riksförbund (2005) Du ska inte tro det blir sommar, rapport 6 .

Markström, Ann-Marie \& Münger, Ann-Charlotte (2004) "Socialpedagogiska institutioner i tid och rum». I Lisbeth Eriksson, Hans-Erik Hermansson, Ann-Charlotte Münger (red.) Socialpedagogik och samhällsförståelse. Teori och praktik $i$ socialpedagogisk forskning. Stockholm: Brutus Östlings bokförlag Symposion.

Mason, Jennifer (2002) Qualitative researching. London: Sage.

Michalski Joseph, Mishna Faye \& Cummings Richard (2003) "A Multi-Method Impact Evaluation of a Therapeutic Summer Camp Program». Child and Adolescent Social Work Journal vol. 20, nr 1, pp. 53- 76.

Münger, Ann-Charlotte (2000) Stadens barn på landet. Stockholms skollofskolonier och den moderna välfärden. Linköping: Linköpings Universitet.

Olson, Hans-Eric (1992) Staten och ungdomens fritid. Kontroll eller autonomi. Lund: Arkiv.

Parton Nigel, Thorpe David \& Waatam Corinne (1997) Child Protection. Risk and the Moral Order. Basingstoke: Macmillan Press.

Petersson, Gunilla (2006) „Närvarande mödrar och tillräckligt frånvarande fäder. Om socialtjänstens bedömningar av föräldrars omsorg", Socialvetenskaplig tidskrift vol. 13, nr 1, s. 51-65.

Riemann, Gerhard (2005) "Trying to Make Sense of Social Workers'Case Discussions", Qualita tive Social Work vol. 4, nr 4, pp. 413-430.

SFS (1960:595) Stadga för barnavårdsanstalter.

Ann-Charlotte Münger: I utkanten av den sociala barnavården. 
Sheppard, Michael \& Woodcook, Johanna (1999) "Need as an Operating Concept: the Case of Social Work with Children and Families", Child and Family Social Work vol. 4, nr 1, pp. 67-76.

Smith, Gilbert (1980) Social Needs: Policy, Practice and Research. London: Routledge.

Socialstyrelsen (2006) Lägesrapporter 2005. Individ och familjeomsorgen.

Socialstyrelsen (2007) Social barnavaird $i$ förändring. Slutrapprot från BBIC-projektet.

SOU 2000:38 Välfärd, vård och omsorg.

Vetenskapsrådet (2002) Forskningsetiska principer inom humanistisk-samhällsvetenskaplig forskning.

Ward, Harriet (2002) (red.) Approaches to Needs Assessment in Childrens's Services. London: Jessica Kingsleys Publishers.

White, Sue (2003) »The Social Worker as Moral
Judge: Blame, Responsibility and Case formulation«. I Christofer Hall, Kirsi Juhila and Tarja Pösö (red.) Constructing Clienthood in Social Work and Human Services. Interaction, Identities and Practices. London: Kingsley Publishers.

Wiklund, Stefan (2006) „Barnavårdsinsatser en studie av kommunala skillnader", Socialvetenskaplig tidskrift vol. 13, nr 3, s. 244-259.

Wodarski John, Feldman Ronald \& Pedi Stephen (1976) "Integrating Antisocial Children into Pro Social Groups at Summer Camp: A Three -Year Study", Social Service Review vol. 50, nr 2, pp. 256-272.

Otryckt material

Ansökningsblanketter (2004)

Barnstaplar (2003)

Verksamhetsberättelser 1960-2004 för kolonier i kommun.

\section{Summary}

\section{On the outskirts of social child care. Who is entitled to a place in a summer camp?}

One of the most characteristic signs of Swedish social policy is that it consists to a large extent of welfare services. A very important set of services is intended to support children and adolescents with different problems and needs. These various services are available both in social child care and in municipal outpatient care. An activity that is found in both of these institutions is the Swedish summer camps. The task of the summer camps is complex because it is a leisure activity for all children in a municipality while it is used as a measure in social child care. The main objective of the summer camps and their activities is to give the children and adolescents the opportunity to take part in activities and to get experiences that they would not be able to have with their families during the summer vacations. The purpose of this article is to study the selection process used to determine which children and adolescents will be offered the possibility to go to a camp in a municipality with limited capacity. The empirical material consists of observational studies and interviews performed during fieldwork. It was collected during two meetings where 
children and adolescents were selected for three-week summer camps in the municipality. The result shows that the work, which should be governed by an established priority list, is a complex process where the concept of need is an important criterion. How the concept should be understood and used is not defined, however, and the evaluation and selection is therefore to a large extent governed by moral opinion and previous experiences among the persons in the selection committee. There is also a pragmatic explanation: According to an unwritten rule, one third of each summer camp group consists of children with social problems and needs, one third of children with previous summer camp experience, and the last third of children without social problems or needs. The selection process is therefore characterized by an assessment which has to balance the individual needs and problems of the child against the group needs/activities. 